\title{
Leucocyte sodium efflux and electrolyte content in insulin treated diabetes
}

\author{
L. L. Ng, D. Simmons, M. Harker and T.D. R. Hockaday \\ Sheikh Rashid Diabetes Unit, Radcliffe Infirmary, Oxford, UK
}

Summary. Leucocyte sodium efflux and sodium content were studied in 41 insulin treated diabetic patients and compared to 41 age, body mass index and blood pressure matched nondiabetic control subjects. Fasting leucocyte ${ }^{22} \mathrm{Na}$ ouabainsensitive efflux rate constants were lower in diabetic patients (median [range] 2.30 [1.04-3.73] versus $2.45[1.57-3.95] \mathrm{h}^{-1}$, $p<0.04$ ) suggesting a reduced sodium pump activity. The ${ }^{22} \mathrm{Na}$ oubain-insensitive efflux rate constant which reflects passive sodium efflux was raised in insulin treated diabetes
(0.92 [0.42-1.73] versus $\left.0.79[0.28-1.49] \mathrm{h}^{-1}, p<0.01\right)$. Leucocyte sodium content was raised in the diabetic patients $(47.7$ [26.9-93.4] versus 26.5 [15.9-67.7] $\mathrm{mmol} / \mathrm{kg}, p<0.0001)$. Abnormal cellular sodium handling could lead to hypertension or other complications in diabetes.

Key words: Diabetes, leucocyte, sodium, adenosine-triphosphatase.
Type 1 (insulin-dependent) and Type 2 (non-insulindependent) diabetes are associated with a higher prevalence of hypertension [1,2] and this may be one factor associated with the development of diabetic nephropathy [3, 4], a major cause of mortality in such patients. However, the mechanisms leading to the development of hypertension in diabetes are at present unclear, although some evidence for involvement of the catecholamine and renin-angiotensin systems exists [1], and genetic factors may also play a part [5]. One other unexplored possibility is the role of altered cellular sodium handling in diabetes.

Many cellular sodium transport abnormalities have been described in essential hypertension [6], including reduced leucocyte sodium efflux via the sodium pump [7] and increased erythrocyte $\mathrm{Li}^{+} / \mathrm{Na}^{+}$exchange [8]. The defects in leucocyte $\mathrm{Na}^{+}$handling may explain the raised cellular $\mathrm{Na}^{+}$content in hypertension [7]. Also, such defects in leucocyte sodium pump activity may be genetically determined and exist even before the onset of hypertension $[9,10]$. In Type 1 diabetes, erythrocyte $\mathrm{Na}^{+}-\mathrm{K}^{+}$-ATPase activity is reduced [11], but there is no published work that we know of on human nucleated cells. Human leucocytes have been used as a model of vascular smooth muscle, the sodium pump activity of both being correlated [12]. We therefore studied leucocyte $\mathrm{Na}^{+}$efflux and intracellular electrolytes in insulin treated diabetic patients and compared them to a group of age, body mass index and blood pressure matched non-diabetic control subjects.

\section{Subjects and methods}

All chemicals were Analar. ${ }^{22} \mathrm{Na}$ was from Amersham International (Aylesbury, Bucks., UK), TC199 (tissue culture fluid) from Wellcome Diagnostics Dartford, Kent, UK, and ouabain from the Sigma Chemical Company Poole, Dorset, UK.

\section{Subjects}

Forty-one insulin treated diabetic patients from the diabetic clinic (diastolic blood pressure $<95 \mathrm{~mm} \mathrm{Hg}$ ) and 41 age, body mass index and blood pressure matched non-diabetic subjects from local companies were studied after an overnight fast. All patients gave informed consent and the study was approved by the local ethics committee.

On arrival at 09.00 hours, an intravenous cannula was inserted and subjects rested supine for $30 \mathrm{~min}$. Resting blood pressures were measured on a random zero sphymomanometer by one observer, and the average of 3 values were reported. Eighty $\mathrm{ml}$ of blood was taken for plasma glucose, insulin, glycated haemoglobin and leucocyte sodium efflux and electrolyte studies. Subjects were excluded if they were on diuretics, beta-blockers, calcium antagonists, angiotensin-converting enzyme antagonists, oral contraceptives or anti-depressants, if they had had any infection within the previous month, or if their body weight had not been stable $( \pm 3 \mathrm{~kg})$ for the last 
6 months. Also, all diabetic patients with hypertension, microalbuminuria, frank proteinuria or renal failure were excluded from the study. The diabetic patients omitted their human insulin on the day of the study. All subjects had normal plasma creatinine and electrolyte concentrations, and had no other endocrine disorder.

\section{Leucocyte electrolyte content and efflux studies}

Leucocytes were isolated from blood by dextran sedimentation as previously described [13]. $40 \mathrm{ml}$ of blood (anticoagulated with preservative free sodium heparin $200 \mathrm{U}$ ) was mixed with $10 \mathrm{ml}$ dextran $(60 \mathrm{~g} / 1 \mathrm{TC} 199)$. After allowing the erythrocytes to settle for $30 \mathrm{~min}$, the leucocyte-rich supernatant was carefully aspirated off and centrifuged at room temperature for $5 \mathrm{~min}$ at $160 \mathrm{~g}$. Residual erythrocytes were lysed by hypo-osmotic shock. The leucocytes were washed once with TC199, and then half of the leucocytes were used for ${ }^{22} \mathrm{Na}$ efflux studies. Briefly, leucocytes were loaded with ${ }^{22} \mathrm{Na}$ in TC199 (final specific activity $1110 \mathrm{MBq} / \mathrm{l}$ ) at $37^{\circ} \mathrm{C}$ for $30 \mathrm{~min}$. After centrifugation and one wash with $\mathrm{TC} 199$ at room temperature to remove most of the extracellular ${ }^{22} \mathrm{Na}$, the efflux of ${ }^{22} \mathrm{Na}$ was measured into prewarmed $\left(37^{\circ} \mathrm{C}\right) \mathrm{TC} 199$ over $20 \mathrm{~min}$ in the presence and absence of ouabain, $10^{-4} \mathrm{~mol} / \mathrm{l}$. Aliquots of cell suspension were pipetted at 4-min intervals into precooled Eppendorf tubes and spun down immediately. The radioactivity was measured in cell pellets and supernatants on a gamma counter. Efflux rate constants (ERC) were calculated from the slope of the regression of $\log _{e}$ cellular radioactivity against time and expressed as $\mathrm{h}^{-1}$. All ERC determinations had regression coefficients of greater than 0.99 . The ouabain-sensitive ERC was defined as the difference between total and ouabain-insensitive ERC and reflects the activity of the sodium pump. The within-individual coefficient of variation for the ouabain-sensitive ERC was 7\%, and that for the ouabain-insensitive ERC was $13 \%$.

Intracellular electrolytes were measured in the other half of the leucocyte pellet. These were determined in fasting subjects as the level of intracellular $\mathrm{Na}^{+}$rises post-prandially [13]. The leucocytes were resuspended in TC199 at $37^{\circ} \mathrm{C}$ for $30 \mathrm{~min}$ so that intracellular $\mathrm{Na}^{+}$, which tends to rise if cells are kept at room temperature, falls to a stable level. Thus, this half of the leucocyte pellet was treated identically and concurrently to that half of the pellet loaded with

${ }^{22} \mathrm{Na}$ for efflux studies, i.e. both had a period of incubation for $30 \mathrm{~min}$ in TC199 at $37^{\circ} \mathrm{C}$. This ensured that electrolyte composition in leucocyte pellets was similar for both the ${ }^{22} \mathrm{Na}$ efflux and intracellular electrolyte studies. After this period of incubation, the leucocytes were then spun down and washed three times with cold $\left(4^{\circ} \mathrm{C}\right)$ isotonic magnesium chloride buffer $\left(\mathrm{MgCl}_{2}, 95 \mathrm{mmol} / 1\right.$, Tris base $5 \mathrm{mmol} / 1, \mathrm{pH} 7.4$ with $\mathrm{HCl}$ ). There is minimal loss of cellular $\mathrm{Na}^{+}$ with this washing procedure [13]. Pellets were then dried in an oven at $80^{\circ} \mathrm{C}$ for $24 \mathrm{~h}$ before determining the dry weight to the nearest microgram. The residue was then dissolved in $1 \mathrm{~mol} / 1$ nitric acid, and $\mathrm{Na}^{+}$and $\mathrm{K}^{+}$measured by flame photometry. The intracellular electrolytes are expressed as $\mathrm{mmol} / \mathrm{kg}$ dry weight. The within-individual coefficient of variation for intracellular $\mathrm{Na}^{+}$was $11 \%$ and that for $\mathrm{K}^{+}$was $9 \%$.

\section{Other assays}

Plasma glucose was measured by a glucose oxidase method, and glycated haemoglobin by agar gel electrophoresis [14].

\section{Statistical analysis}

All results are expressed as median [range]. The Mann-Witney U test was used to compare the plasma and cellular measurements. Spearman correlation coefficients are reported.

\section{Results}

The insulin-treated diabetic patients and the nondiabetic control subjects were well matched for age, body mass index and both systolic and diastolic blood pressure (Table 1). The duration of diagnosed diabetes in the patients ranged from 6 months to 40 years. Although the leucocyte total ${ }^{22} \mathrm{Na}$ ERC did not differ in the 2 groups (diabetic subjects 3.18 [1.83-5.46] versus non-diabetic subjects $\left.3.17[2.13-4.79] \mathrm{h}^{-1}, p=\mathrm{NS}\right)$, the ouabain-sensitive ERC was lower in diabetic patients (diabetic patients 2.30 [1.04-3.73] vs control subjects, $2.45[1.57-3.95] \mathrm{h}^{-1}$, Fig. $\left.1, p<0.04\right)$ and the ouabaininsensitive ERC was higher (diabetic patients, 0.92 $[0.42-1.73]$ vs control subjects, $0.79[0.28-1.49] \mathrm{h}^{-1}$, Fig. $1, p<0.01$ ). Thus, active $\mathrm{Na}^{+}$efflux per unit of intracellular $\mathrm{Na}^{+}$via the sodium pump was reduced, and passive $\mathrm{Na}^{+}$efflux was increased in the diabetic patients. Table 1 shows the very significantly increased leucocyte intracellular $\mathrm{Na}^{+}$and $\mathrm{K}^{+}$content in diabetic patients (intracellular $\mathrm{Na}^{+}$, diabetic patients 47.7 [26.9-93.4] vs control subjects, 26.5 [15.9-67.7] $\mathrm{mmol} / \mathrm{kg}, p<0.0001$; intracellular $\mathrm{K}^{+}$, diabetic patients 402 [246-688] vs control subjects, 348 [202-514] $\mathrm{mmol} / \mathrm{kg}, p<0.006$ ). The differences in $\mathrm{Na}^{+}$transport and electrolyte content were not due to differences in differential white cell count (diabetic patients, total

Table 1. General characteristics, plasma measurements and leucocyte intracellular electrolytes in insulin-treated diabetic patients and non-diabetic control subjects. Results are expressed as median [range]

\begin{tabular}{|c|c|c|}
\hline & $\begin{array}{l}\text { Insulin-treated } \\
\text { diabetes }\end{array}$ & Non-diabetic \\
\hline Number (male) & $41(25)$ & $41(29)$ \\
\hline $\begin{array}{l}\text { Age } \\
\text { (years) }\end{array}$ & $41[22-69]$ & $40[16-65]$ \\
\hline $\begin{array}{l}\text { Body Mass Index } \\
\left(\mathrm{kg} / \mathrm{m}^{2}\right)\end{array}$ & $23.3[19.4-30.2]$ & $23.0[19.1-29.7]$ \\
\hline $\begin{array}{l}\text { Systolic blood } \\
\text { pressure }(\mathrm{mm} \mathrm{Hg})\end{array}$ & $123[99-161]$ & $120[100-141]$ \\
\hline $\begin{array}{l}\text { Diastolic blood } \\
\text { pressure }(\mathrm{mm} \mathrm{Hg})\end{array}$ & $75[53-90]$ & $79[50-88]$ \\
\hline $\begin{array}{l}\text { Insulin dose } \\
\text { (units/day) }\end{array}$ & $47[24-80]$ & - \\
\hline $\begin{array}{l}\text { Fasting plasma } \\
\text { glucose }(\mathrm{mmol} / \mathrm{l})\end{array}$ & $13.0 \quad[3.1-22.9]$ & $5.1 \quad[4.5-5.8$ \\
\hline $\begin{array}{l}\text { Glycated haemoglobin } \\
(\%)\end{array}$ & $10.1 \quad[6.7-14.9]$ & - \\
\hline \multicolumn{3}{|l|}{ Leucocyte measurements } \\
\hline $\begin{array}{l}\text { Intracellular } \mathrm{Na}^{+} \\
(\mathrm{mmol} / \mathrm{kg})\end{array}$ & $47.7[26.9-93.4]^{\mathrm{a}}$ & $26.5[15.9-67.7]$ \\
\hline $\begin{array}{l}\text { Intracellular } \mathrm{K}^{+} \\
(\mathrm{mmol} / \mathrm{kg})\end{array}$ & $402[246-688]^{a}$ & $348[202-514]$ \\
\hline
\end{tabular}

${ }^{a} p<0.001$ compared to non-diabetic control subjects 


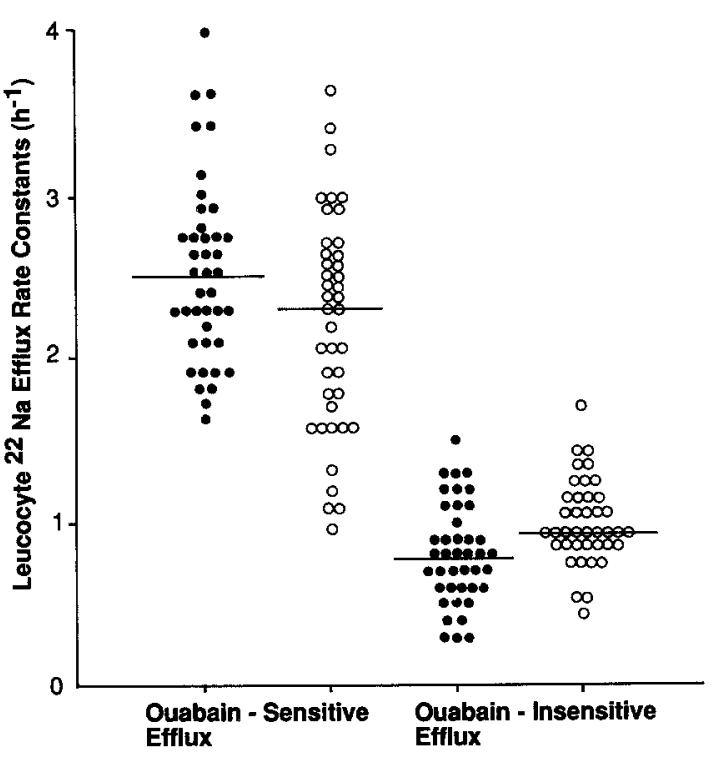

Fig. 1. Leucocyte ouabain-sensitive and insensitive ${ }^{22} \mathrm{Na}$ efflux rate constants in 41 non-diabetic subjects $(0)$ and 41 age, body mass index and blood pressure matched diabetic patients $(O)$. Medians are plotted

leucocyte count $6.1[3.3-9.8] \times 10^{9} 1^{-1}$, polymorphonuclear leucocytes 63 [36-77] \%, lymphocytes 27 [17-52] $\%$; control subjects, total leucocyte count 5.9 [3.5-9.5] $\times 10^{9} 1^{-1}$, polymorphonuclear leucocytes 57 [42-68] \%, lymphocytes 31 [24-46] \%).

In the diabetic patients, no significant correlations were found between the measurements of total, ouabain-insensitive and sensitive ${ }^{22} \mathrm{Na}$ efflux rate constants and intracellular electrolytes and the levels of glycated haemoglobin or fasting plasma glucose.

\section{Discussion}

Although a reduced $\mathrm{Na}^{+}, \mathrm{K}^{+}$-ATPase activity in the erythrocytes of Type 1 diabetic patients has been described [11], there has been no investigation of $\mathrm{Na}^{+}$ transport mechanisms in human nucleated cells from diabetic patients. In this study, the leucocyte ${ }^{22} \mathrm{Na}$ ouabain-sensitive ERC, which reflects active $\mathrm{Na}^{+}$efflux via the sodium pump was reduced in the insulin treated diabetic patients. This would in turn lead to an elevation of intracellular $\mathrm{Na}^{+}$. These findings were not due to differences in differential white cell count, for these values were similar in the diabetic and control groups studied. Furthermore, we have shown previously that polymorphonuclear leucocytes and lymphocytes have similar electrolyte contents [13]. Finotti and Palatini [11] failed to demonstrate a raised intracellular $\mathrm{Na}^{+}$in Type 1 diabetes even with a reduced $\mathrm{Na}^{+}, \mathrm{K}^{+}$-ATPase activity, although they also found an abnormally high level of a plasma $\mathrm{Na}^{+}, \mathrm{K}^{+}$-ATPase stimulator in diabetes, which may have restored the erythrocyte sodium pump activity to normal in vivo. In addition, we have also found a raised intracel- lular $\mathrm{K}^{+}$content in diabetes, but have no information on the $\mathrm{K}^{+}$permeability of the leucocytes. In animal models of diabetes, the onset of diabetes has been associated with a lowered $\mathrm{Na}^{+}, \mathrm{K}^{+}$-ATPase activity in nerve [15], dorsal root ganglia [16], heart [17] and muscle [18]. Further, Moore et al. found a raised soleus muscle intracellular $\mathrm{Na}^{+}$in rats with streptozotocin diabetes [18]. Our findings with the human leucocyte confirm these findings in other nucleated cells from animal tissue. However, the intracellular electrolyte content of cells incubated in tissue culture media in vitro may well differ from the intracellular composition of cells in contact with plasma in-vivo.

The ouabain-insensitive ERC was raised in insulintreated diabetes. This passive $\mathrm{Na}^{+}$efflux is composed of $\mathrm{Na}^{+} / \mathrm{Na}^{+}$exchange, loop diuretic-sensitive $\mathrm{Na}^{+}$, $\mathrm{K}^{+}, \mathrm{Cl}^{-}$cotransport and membrane $\mathrm{Na}^{+}$permeability. We have not used the inhibitors phloretin or bumetanide to fractionate this passive efflux further. This increased passive efflux could be a compensatory response to intracellular $\mathrm{Na}^{+}$accumulation.

Increased erythrocyte $\mathrm{Na}^{+}, \mathrm{K}^{+}, \mathrm{Cl}^{-}$cotransport has been described in essential hypertension [19]. Lithium-sodium exchange in erythrocytes, which may be a measure of $\mathrm{Na}^{+} / \mathrm{Na}^{+}$exchange, is also raised in essential hypertension [8]. The lowered sodium pump activity in leucocytes from hypertensive subjects is also well documented $[6,7,9]$. The diabetic patients in this study had diastolic blood pressures less than $95 \mathrm{~mm} \mathrm{Hg}$, but whether the possession of such membrane transport defects could indicate a predisposition to the development of hypertension is not known at present. Such impairment of membrane transport systems has been observed in essential hypertension before the rise in blood pressure [10] and may be a genetic marker of susceptibility to the disease. As the parents of diabetic patients with nephropathy have higher blood pressures [5], and abnormally raised erythrocyte $\mathrm{Li}^{+} / \mathrm{Na}^{+}$exchange has been found in diabetic nephropathy [20], it is uncertain to what extent the defects in leucocyte $\mathrm{Na}^{+}$transport may be markers of later development of hypertension or nephropathy.

A further consequence of intracellular $\mathrm{Na}^{+}$accumulation due to reduced active $\mathrm{Na}^{+}$efflux may be a lowering of the influx of metabollites which are dependent on the inward $\mathrm{Na}^{+}$gradient to drive them into the cell against their concentration gradient. Examples include amino-acids [21] and inositol [22], and there is evidence for impaired uptake of such substances in animal diabetic tissue [22, 23]. Whether a deficiency of such substances could lead to some of the complications of diabetes, like neuropathy, is unknown.

In conclusion, leucocytes from insulin-treated diabetic patients had a lowered ouabain-sensitive ${ }^{22} \mathrm{Na}^{+}$efflux rate constant and a raised ouabain-insensitive ${ }^{22} \mathrm{Na}$ efflux rate constant. The intracellular 
$\mathrm{Na}^{+}$content was raised, probably a consequence of reduced sodium pump activity. Such abnormalities in membrane $\mathrm{Na}^{+}$transport could exist even in the absence of the vascular or renal complications of diabetes, but whether they indicate susceptibility to complications such as nephropathy or hypertension is at present unknown.

Acknowledgements. We are grateful for the Oxford Diabetes Trust's support of the Sheikh Rashid Diabetes Unit. LLN held a Medical Research Council Training Fellowship and DS is a Eli Lilly BDA research fellow. We also thank the Sir Jules Thorn Charitable Trust and the British Heart Foundation for their generous support.

\section{References}

1. Drury PL (1983) Diabetes and arterial hypertension. Diabetologia 24: $1-9$

2. Pell S, D'Alonzo CA (1967) Some aspects of hypertension in diabetes mellitus. J Am Med Assoc 202: 104-110

3. Wiseman MJ, Viberti GC, Mackintosh D, Jarrett RJ, Keen $\mathrm{H}$ (1984) Glycaemia, arterial pressure and microalbuminuria in Type 1 (insulin-dependent) diabetes mellitus. Diabetologia 26: 401-405

4. Mogensen CE, Christensen CK (1984) Predicting diabetic nephropathy in insulin-dependent patients. $\mathrm{N}$ Engl $\mathrm{J}$ Med 311: 89-93

5. Viberti GC, Keen H, Wiseman MJ (1987) Raised arterial pressure in parents of proteinuric insulin-dependent diabetics. $\mathrm{Br}$ Med J 295: 515-517

6. Hilton PJ (1986) Cellular sodium transport in essential hypertension. N Engl J Med 314: 222-229

7. Edmondson RPS, Thomas RD, Hilton PJ, Patrick J, Jones NF (1975) Abnormal leucocyte composition and sodium transport in essential hypertension. Lancet II: 1003-1005

8. Canessa M, Adragna N, Solomon HS, Connolly TM, Tosteson DC (1980) Increased sodium-lithium countertransport in red cells of patients with essential hypertension. $\mathrm{N}$ Engl J Med 302: $772-776$

9. Heagerty AM, Milner M, Bing RF, Thurston H, Swales JD (1982) Leucocyte membrane sodium transport in normotensive populations: dissociation of abnormalities of sodium efflux from raised blood pressure. Lancet II: $894-896$

10. Woods KL, Beevers DG, West M (1981) Familial abnormality of erythrocyte cation transport in essential hypertension. Br Med J 282: $1186-1188$

11. Finotti P, Palatini P (1986) Reduction of erythrocyte $\left(\mathrm{Na}^{+}-\mathrm{K}^{+}\right)$ ATPase activity in Type 1 (insulin-dependent) diabetic subjects and its activation by homologous serum. Diabetologia 29: $623-628$
12. Aalkjaer C, Heagerty AM, Parvin SD, Bell PRF, Bing RF, Swales JD (1986) Cell membrane sodium transport: a correlation between human resistance vessels and leucocytes. Lancet I: 649-651

13. Ng LL, Bruce MA, Hockaday TDR (1987) Leucocyte sodium pump activity after meals or insulin in normal and obese subjects: Cause for increased energetic efficiency in obesity? Br Med J 295: 1369-1373

14. Menard L, Dempsey ME, Blankstein LA, Aleyassine H, Wacks M, Soeldner JS (1980) Quantitative determination of glycosylated hemoglobin $\mathrm{A}_{1}$ by agar gel electrophoresis. Clin Chem 26: $1598-1602$

15. Greene DA, Lattimer SA (1983) Na/K ATPase defect in diabetic rat peripheral nerve: correction by myo-inositol administration. $\mathbf{J}$ Clin Invest 72: 1050-1063

16. Green RJ, King RHM, Thomas PK, Baron DN (1985) Sodium potassium-ATPase activity in the dorsal root ganglia of rats with streptozotocin-induced diabetes. Diabetologia 28: 104-107

17. Pierce GN, Dhalla NS (1983) Sarcolemmal $\mathrm{Na}^{+}-\mathrm{K}^{+}$-ATPase activity in diabetic rat heart. Am J Physiol 243: C241-C247

18. Moore RD, Munford JW, Pillsworth Jr TJ (1983) Effects of streptozotocin diabetes and fasting on intracellular sodium and adenosine triphosphate in rat soleus muscle. J Physiol 338: 277-294

19. Garay RP, Dagher G, Pernollet MG, Devynk MA, Meyer P (1980) Inherited defect in $\mathrm{Na}^{+}-\mathrm{K}^{+}$-cotransport system in erythrocytes from essential hypertensive patients. Nature 284: 281-283

20. Mangili R, Bending JJ, Scott G, Li LK, Gupta A, Viberti GC (1988) Increased sodium-lithium countertransport activity in red cells of patients with insulin dependent diabetes and nephropathy. N Engl J Med 318: 146-150

21. Schultz SG, Fuisz RE, Curran PF (1966) Amino acid and sugar transport in rat ilium. J Gen Physiol 49: 849-866

22. Greene DA, Lattimer SA (1982) Sodium and energy-dependent uptake of myo-inositol by rabbit peripheral nerve. Competitive inhibition by glucose and lack of an insulin effect. J Clin Invest 70: 1009-1018

23. Thomas PK, Wright DW, Tzebelikos E (1984) Amino acid uptake by dorsal root ganglia from streptozotocin-diabetic rats. $J$ Neurol Neurosurg Psychiatr 47: 912-916

Received: 13 June 1988

and in revised form: 26 September 1988

Dr. L.L. Ng

Sheikh Rashid Diabetes Unit

Radcliffe Infirmary

Oxford, OX2 6HE

UK 